\title{
The head leads to the heart
}

Benzi M. Kluger, MD, MS, FAAN

Neurolog ${ }^{\circledR}$ 2018;91:713-714. doi:10.1212/WNL.0000000000006326

I was born into a fairly typical American Jewish family, one that valued social justice and tradition over religion. Nonetheless, I regularly went to synagogue and Hebrew School and in my own way believed in the importance of God and religion. However, by the time of my Bar Mitzvah, I already had serious misgivings about Judaism and the teachings of the Torah. These misgivings arose, in part, out of my careful reading of the Torah, my burgeoning interest in science, and my love of professional wrestling. Why did the Torah claim to be able to cure leprosy by sprinkling a person 7 times with a live dove dipped into the blood of a freshly slain dove? Why did it refer to dolphins as fishes when they were clearly mammals? And, perhaps most importantly, when would my prayers to grow to the size of Andre the Giant be answered?

My skepticism grew through college and my faith was finally and completely broken when, despite my fervent nightly prayers and other attempts at deal-making with God, my father died of cancer. I had shared with him the news of my acceptance to medical school less than 24 hours before his death.

As this story goes, his death was appropriately timed. Medical school marked a shift in my faith. Although I thought I had lost all faith, instead I adopted an invisible faith, as did many of my classmates, in the religion of science.

Like other religions, science has its own dogma and its own heresy. Looking back now, I cringe at how blindly and fanatically I clung to this faith. I recall during this time my absolute shock upon learning that one of my neurology attendings went to church on a regular basis. I was honestly perplexed. In my mind, this was akin to treating leprosy with the blood of a dove. This was faith in a church outside of the church of science. It was heresy.

Ironically, the few teaching sessions I received on spirituality in medical school primarily served to reinforce this attitude. My impression was that the people teaching spirituality were untrained volunteers who had little connection with patients and were brought on by the school primarily to pander to politically correct pressures to balance the curriculum. As an example, I specifically recall being taught how to take a spiritual history as a first-year medical student and wondering who came up with this exercise. I never saw this skill practiced in my continuity clinic or had an attending ask me for spiritual information as a medical student, and I never would as an intern, resident, or fellow.

I chose the field of neurology, and later the subspecialty of behavioral neurology, in part because it seemed to be the field that most clearly demonstrated the advances of science in understanding human behavior and in refuting the antiquated ideas of spirit, soul, and free will. If even the most subtle of human abilities and desires could be transformed in an instant by a lesion in the brain, as my newfound heroes showed, how could one argue that belief in an immaterial soul has any bearing on the important and life-changing work of physicians in the real world?

My faith in science continued unseen, unquestioned, and unchallenged until I completed my fellowships in behavioral neurology and movement disorders and began seeing my own patients in my own practice. Something in the way I now saw them and they saw me challenged this worldview.

\section{Correspondence}

Dr. Kluger

benzi.kluger@ucdenver.edu

MORE ONLINE

\section{ค Audio}

Listen to Dr. Kluger read this essay.

NPub.org/hwcpng 
I now saw their stories played out over time rather than as snapshots. There was no longer any joy in making a brilliant diagnosis of an incurable illness because I now knew the full scope of the tragedy that followed. And not just for one person. For whole families, sometimes whole communities.

Perhaps more importantly, I felt the people coming to me for help expected something that I didn't know how to give: an answer to their suffering. Like many junior faculty, I worried about whether I was cut out for a career in clinical research and whether I would ever write a successful grant. But these concerns soon gave way to darker existential doubts concerning medicine in general and my inability to address the suffering of my patients and their families. This was not about how to treat depression or pain. It was about how to deal with the sadness, anger, frustration, fear, and guilt that arose in patients and families during the course of neurodegenerative illnesses. I knew these emotions were not pathologic because I also suffered when I put myself in my patients' shoes. I felt the hopelessness of their situation and my own helplessness before them and it deeply disturbed me.

It was during this dark night of the soul that I began searching, determined to either find a solution or dedicate my life to a new path. When I talked to other colleagues in neurology about this, they acknowledged having similar feelings and mostly suggested that I try to not dwell on it too much.

In my existential despair, I spent a week on a Zen Buddhist retreat in the hope of finding wisdom that would help me to better understand and work with suffering. While there, I spent time with a monk who regularly volunteered at hospices. While the idea of working in hospice as a doctor made me nervous even with the armor of medical training, the idea of being an "untrained" volunteer around dying people gave me serious anxiety. When I asked him what he was able to offer, he said the most important thing was to be present and open. To honestly share the experience of also being someone who was dying and experienced suffering instead of pretending that this person in front of you was somehow different than you.

With the idea of just being with suffering, of being open and authentic, something inside of me began to shift.

A few months later, I saw one of my favorite patients, a 19year-old girl with Huntington disease whose 17-year-old sister died in home hospice earlier that year. During this visit, she complained of insomnia, and when I asked her why, she told me, "I'm afraid of dying in my sleep." I don't remember being particularly skilled in the conversation that followed but I remember being open and staying present with her and her fear. By making this admission in front of her family and me, she was no longer alone in her fear and began to sleep better. A lightbulb went on - this is a spiritual problem. And one that doesn't require a belief in magic.

Since then, I have had the good fortune to cross paths with several leaders in palliative care who piqued my curiosity in this field and who never tried to dissuade me from being open to, and staying with, the suffering I saw. I delved deeply into palliative care, took a few workshops, and saw that this approach was needed in neurology and would help not only my patients but also alleviate my own helplessness. In 2013, I started a team-based palliative care clinic for patients with neurologic disease. This team included a chaplain, so as to be able to address the very real and yet immaterial suffering that troubled me and my patients, so much of which was spiritual in its origin and in its solution.

As I've continued in this work I see more and more how important the spiritual dimension of care is for both my patients and for the meaning of the work that I do. In the last year, I feel I've come full circle on my spiritual journey. I now begin my clinic day with the palliative care team setting intentions and listening to a spiritual reading from our chaplain to remind me of why I'm here and whom I'm trying to help. 


\section{Neurology}

The head leads to the heart

Benzi M. Kluger

Neurology 2018;91;713-714

DOI 10.1212/WNL.0000000000006326

This information is current as of October 8, 2018

\section{Updated Information \& Services}

\section{Subspecialty Collections}

Permissions \& Licensing

\section{Reprints}

including high resolution figures, can be found at: http://n.neurology.org/content/91/15/713.full

This article, along with others on similar topics, appears in the following collection(s):

\section{Palliative care}

http://n.neurology.org/cgi/collection/palliative_care

Information about reproducing this article in parts (figures,tables) or in its entirety can be found online at:

http://www.neurology.org/about/about_the_journal\#permissions

Information about ordering reprints can be found online:

http://n.neurology.org/subscribers/advertise

Neurology ${ }^{\circledR}$ is the official journal of the American Academy of Neurology. Published continuously since 1951, it is now a weekly with 48 issues per year. Copyright () 2018 American Academy of Neurology. All rights reserved. Print ISSN: 0028-3878. Online ISSN: 1526-632X.

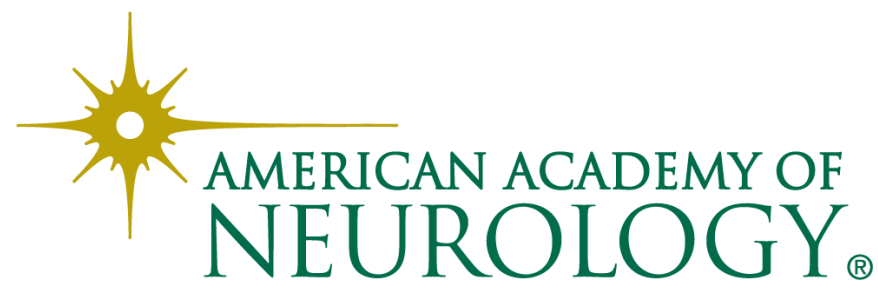

